\title{
The effects of the aromatase inhibitor fadrozole hydrochloride on fetuses and uteri in late pregnant rats
}

\author{
H Tamada, Y Shimizu, T Inaba ${ }^{1}$, N Kawate and T Sawada \\ Laboratory of Theriogenology, Graduate School of Agriculture and Biological Sciences, Osaka Prefecture University, Sakai, Osaka 599-8531, Japan \\ ${ }^{1}$ Laboratory of Cell Pathobiology, Graduate School of Agriculture and Biological Sciences, Osaka Prefecture University, Sakai, Osaka 599-8531, Japan \\ (Requests for offprints should be addressed to H Tamada; Email: tamada@vet.osakafu-u.ac.jp)
}

\begin{abstract}
It is well known that progesterone and estrogen are essential hormones for maintaining pregnancy in most mammals. Some specific roles of progesterone for the maintenance of pregnancy have been clarified, but the role of estrogen is not well known. This study examines the effects of the aromatase inhibitor, fadrozole hydrochloride (Fad), on fetuses, uterine physical properties and the mRNA expression of the uterine enzymes that are related to collagen metabolism during late pregnancy in rats. Continuous s.c. infusion with $300 \mu \mathrm{g} /$ day Fad from day 14 of pregnancy (day $1=$ the day of sperm detection) reduced the concentration of plasma estradiol- $17 \beta\left(\mathrm{E}_{2}\right)$, and did not change that of plasma progesterone, compared with controls. The treatment increased the intrauterine pressure and reduced the size and compliance of the uterine tissue framework. It also caused injuries (hematomata on the extremities) in about one-quarter of fetuses by day 20 . The collagen content of the uterine ampullae was not changed
\end{abstract}

by the treatment. Uterine mRNA expressions of matrix metalloproteinase-1 (MMP-1), which degrades collagens, and of lysyl oxidase (LO), which is necessary for the formation of intra- and inter-molecular cross-links of collagen, were examined by quantitative RT-PCR. The treatment with Fad had no effect on the expression of MMP-1 mRNA and increased that of LO mRNA. Daily s.c. injection with $0 \cdot 2 \mu \mathrm{g} \mathrm{E}_{2}$ restored the changes in uterine physical properties and the mRNA expression of LO caused by the Fad treatment, and prevented fetal injury, indicating that the influences of Fad treatment are due to estrogen deficiency but not to toxicological effects of Fad. These results imply that estrogen deficiency during late pregnancy in rats obstructs development of the uterine tissue framework so as to cause fetal injury. It is possible that an increase in the uterine expression of LO gene may be involved in this obstruction.

Journal of Endocrinology (2004) 180, 337-345

\section{Introduction}

The synergistic action of progesterone and estrogen is generally held to be essential for most mammals in maintaining fetuses during pregnancy (Courrier 1950). Progesterone is required for decidual growth (Deanesly 1973), and it inhibits the uterine contractions that expel fetuses (Fuchs 1978, Arkaravichien \& Kendle 1992). Uterine immune function is reduced by progesteroneinduced proteins secreted by the uterus (Zhang \& Miller 1989, Liu \& Hansen 1993), and together with estrogen, progesterone develops the uterine tissue framework so as to maintain low intrauterine pressure in the ovariectomized pregnant rat (Ichikawa \& Tamada 1980, Tamada et al. 1984, 1989, 1990). Also, regulation of uterine blood flow by progesterone and estrogen (Ford et al. 1977) may be involved in the maintenance of pregnancy. Thus, some specific roles of progesterone for the maintenance of fetuses have been clarified, but the role of estrogen is relatively unknown.
Availability of an aromatase inhibitor of high specific activity, namely fadrozole hydrochloride (Fad), has enabled us to carry out experiments in which the production of estrogen is inhibited. This study examines the effects of continuous treatment with Fad, during late pregnancy, on the fetus and on physical properties of the uterus in rats. We also looked at the effect of Fad on mRNA expression of the uterine enzymes related to collagen metabolism, since changes in collagen metabolism might be related to the mechanism regulating the physical condition of the uterus.

\section{Materials and Methods}

\section{Animals}

All experiments were conducted in accordance with the Guidelines for Animal Welfare in Research and Education of Osaka Prefecture University. Sprague-Dawley rats bred in our laboratory were housed at $24 \pm 1{ }^{\circ} \mathrm{C}$ with a ratio of 
14 h light:10 h darkness (lights on 0500-1900 h). The rats had free access to standard laboratory food (Rat-P; Nichiwa Mfg Co., Kobe, Japan) and tap water. Females were mated when they were 60-120 days old and had a body weight in the range $180-300 \mathrm{~g}$. The day when spermatozoa were observed in the vaginal smear was designated day 1 of pregnancy. The pregnant rats were divided into three groups. At $1300-1400 \mathrm{~h}$ on day 14 of pregnancy the rats were implanted s.c. with mini-osmotic pumps (Model 2001; Alza Pharmaceuticals, Palo Alto, CA, USA) containing Fad (Fad group). Fad was released at the rate of $300 \mu \mathrm{g} /$ day. Implantation was performed under ether anesthesia on the back, near the neck. Controls were implanted with a mini-osmotic pump containing vehicle (saline). The third group of rats underwent s.c. implantation of a mini-osmotic pump containing Fad, and received $0 \cdot 2 \mu \mathrm{g}$ estradiol- $17 \beta\left(\mathrm{E}_{2}\right)$ daily after the implantation $\left(\mathrm{Fad}+\mathrm{E}_{2}\right.$ group). $\mathrm{E}_{2}$ was dissolved in $0.2 \mathrm{ml}$ sesame oil and injected s.c. at $1400 \mathrm{~h}$ each day. At 1200-1400 h on day 17 of pregnancy, blood samples were collected from the abdominal aorta of rats in the control and Fad group, under ether anesthesia. The plasma was stored at $-30{ }^{\circ} \mathrm{C}$ until the time of hormone assay. At $1000-1200 \mathrm{~h}$ on day 20 of pregnancy, the rats in all three groups underwent laparotomy under ether anesthesia, and the studies described below began. The rats were killed by an overdose of ether.

\section{Hormone assays}

The assays for progesterone, testosterone, androstenedione and $\mathrm{E}_{2}$ were performed by enzyme immunoassay (EIA). Known amounts of the steroids were added to plasma obtained from ovariectomized-adrenalectomized rats, and standard curves were constructed. Progesterone was measured by the EIA method as described by Kawate et al. (1997). Commercial EIA kits were used for the assays of testosterone (Cayman Chemical, Ann Arbor, MI, USA), androstenedione (Oxford Biomedical Research, Inc., Oxford MI, USA) and $\mathrm{E}_{2}$ (Cayman Chemical). The testosterone assay has been described previously (Kuwahara et al. 2000). For the androstenedione assay, steroid in the plasma was extracted by 10 volumes of diethyl ether. The extracts of samples (or standards) and horseradish peroxidase-labeled androstenedione were mixed in the wells, which had been coated with antiandrostenedione antibody, and were incubated at room temperature. The plate was drained and washed three times. Stabilized 3, ${ }^{\prime}, 5,5^{\prime}$-tetramethylbenzidine solution containing hydrogen peroxide was added to each well; the plate was incubated at room temperature and the absorbance of each well was measured with a microtiter plate analyzer (Bio-Rad Laboratories, Richmond, CA, USA). For the $\mathrm{E}_{2}$ assay, extraction was by a similar method to that reported previously (Nagata et al. 1996). In summary, aliquots of plasma were extracted by diethyl ether twice, and dried the extracts were mixed with $1 \mathrm{ml}$ $25 \%$ methanol and $0.5 \mathrm{ml} \mathrm{n}$-hexane. After removal of the n-hexane that contains the detrimental factors for the assay, the methanol was again extracted by diethyl ether. The extracts of samples (or standards), acetylcholinesterase-labeled $\mathrm{E}_{2}$ and antiserum were then mixed in the second antibody-coated wells, and were incubated at room temperature. The plate was then drained and washed three times. Ellman's reagent was then added to each well and the plate was incubated at room temperature, following which the absorbance was measured. The cross-reactivities of the antiandrostenedione antibody for androstenedione, estrone, pregnenolone, deoxycorticosterone, estrone-3-sulfate and $\mathrm{E}_{2}$ were respectively $100,1 \cdot 5,0 \cdot 2,0 \cdot 16,0 \cdot 16$ and $0 \cdot 08 \%$. Cross-reactivities of the anti- $\mathrm{E}_{2}$ antibody for $\mathrm{E}_{2}$, estrone, estriol, testosterone, 5 $\alpha$-dihydrotestosterone, estradiol$17 \alpha$, androstenedione, androstenediol and progesterone were respectively $100,7 \cdot 5,0 \cdot 3,0 \cdot 1,0 \cdot 1,<0 \cdot 01,<0 \cdot 01$, $<0.01$ and $<0.01 \%$. For each assay, all of the samples were quantified within a single assay. The intra-assay coefficient of variation and the lower limit of sensitivity were $8.7 \%$ and $156 \mathrm{pg} / \mathrm{ml}$ for progesterone, $11.7 \%$ and $3.9 \mathrm{pg} / \mathrm{ml}$ for testosterone, $7.9 \%$ and $125 \mathrm{pg} / \mathrm{ml}$ for androstenedione, and $9.7 \%$ and $3.9 \mathrm{pg} / \mathrm{ml}$ for $\mathrm{E}_{2}$.

\section{Determination of intrauterine pressure and classification of fetuses}

The intrauterine pressure was determined for one to four amniotic cavities per rat using a pressure transducer (Nihon Kohden, Tokyo, Japan) immediately after laparotomy. The uterine wall, containing a live fetus, was pricked with a $20 \mathrm{G}$ needle connected to the transducer through a polyethylene tube and the needle was placed in the amniotic cavity. To minimize the effect of the leakage of amniotic fluid through the needle prick on the next determination of intrauterine pressure, the fetuses not contiguous to the already determined ones were chosen for the following determinations. The signal from the transducer was amplified and recorded by a pen recorder. The mean values of the pressures were calculated for each rat.

After determination of the intrauterine pressure, the fetuses and placentae were removed and cleaned. The fetuses were divided into three groups, as reported previously (Tamada \& Ichikawa 1980). Live normal fetuses were defined as those alive without visible signs of injury; injured fetuses were defined as live or recently dead fetuses bearing edematous hematomata; absorbing fetuses were those which were in the process of absorption, either with or without visible hematoma. The number of each category of fetus in each experimental group is expressed as a percentage of the total number of fetuses. The average weight of the live fetuses and their placentae were determined for each rat. 


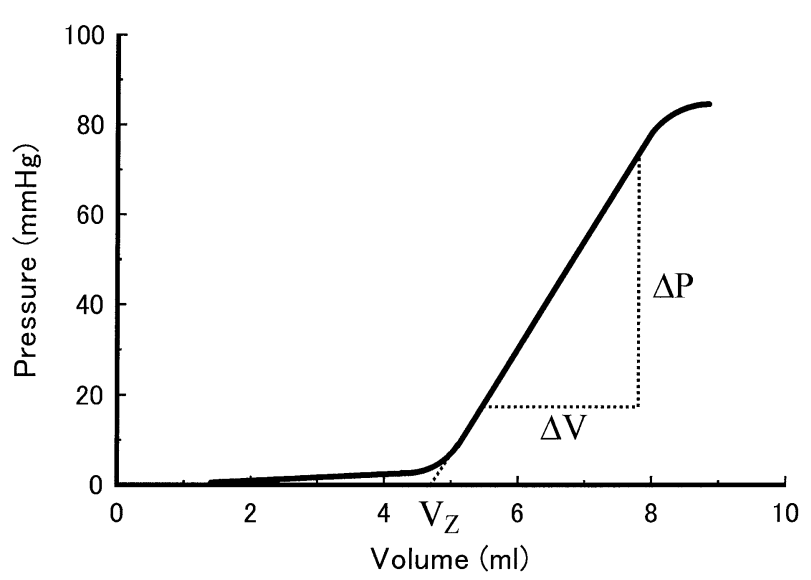

Figure 1 Volume-pressure curve for the rat uterine ampulla on day 20 of pregnancy. $V_{z^{\prime}}$ extrapolation of the linear middle part to zero pressure. The compliance is expressed as the slope $(\Delta \mathrm{V} / \Delta \mathrm{P})$ of the linear segment.

\section{Determination of volume-pressure relationship in the uterine ampulla}

The uterine ampulla in which a live fetus was included was removed, and the volume-pressure curve was determined as reported previously (Tamada et al. 1990). Briefly, the uterine ampulla was suspended in aerated $\mathrm{Ca}$-free Tyrode's solution containing $1.0 \mathrm{mM}$ EGTA at $37^{\circ} \mathrm{C}$. A solution containing $0 \cdot 1 \%$ pontamine sky blue, allowing any leak to be detected, was infused into the uterine ampulla at a rate of $1.0 \mathrm{ml} / \mathrm{min}$, and the pressure and volume in the uterine ampulla during infusion were measured. Figure 1 shows a typical volume-pressure curve. Extrapolation of the linear middle part of the curve to zero pressure defines the intercept $\mathrm{V}_{\mathrm{z}}$, which indicates the size of the uterine tissue framework at zero pressure; the slope $(\Delta \mathrm{V} / \Delta \mathrm{P})$ of the linear region was used as a measure of compliance. The conceptus, with its amniotic and allantoic sacs, was put into a graduated cylinder containing saline, and the increase in volume was measured.

Determination of collagen contents and quantitative analysis of matrix metalloproteinase-1 (MMP-1) and lysyl oxidase (LO) $m R N A$ expression in the uterine ampulla

A uterine ampulla containing a live fetus was taken, and the conceptus was removed. The uterine tissue was cleaned and weighed and frozen immediately in liquid nitrogen. The tissue was stored at $-80{ }^{\circ} \mathrm{C}$ prior to the following studies.

Hydroxyproline was determined by the procedure of Berg (1982), and the value was multiplied by 8.27 to estimate the quantity of collagen. The collagen content in the uterine ampulla was calculated.

Relative expression of MMP-1 and LO mRNA was determined by RT-PCR, using ribosomal protein L19
(RPL19) as an internal standard. Total RNA was extracted from the uterine tissue using acid guanidinium thiocyanate-phenol-chloroform (Chomczynski \& Sacchi 1987). RNAs were quantified by UV absorption measurements and were stored at $-80{ }^{\circ} \mathrm{C}$. One microliter of various concentrations of total RNA was reverse transcribed into cDNA using the Takara RNA PCR Kit (AMV) Version 2 (Takara, Ohtsu, Japan) according to the manufacturer's instructions. The RT was primed with $50 \mu \mathrm{M}$ random-9-mer oligonucleotides, and the same procedure was also performed in the absence of the reverse transcriptase to verify that cDNA was not contaminated with genomic DNA. The reaction mixture was preincubated for $10 \mathrm{~min}$ at $30^{\circ} \mathrm{C}$ prior to cDNA synthesis. The $\mathrm{RT}$ reactions were carried out at $45^{\circ} \mathrm{C}$ for $30 \mathrm{~min}$, followed by heating to $99^{\circ} \mathrm{C}$ for $5 \mathrm{~min}$ to terminate the reaction, and cooling to $5^{\circ} \mathrm{C}$ for 5 min using a MiniCycler (MJ Research, Watertown, MA, USA). The reaction mixture was stored at $-20{ }^{\circ} \mathrm{C}$. After the $\mathrm{RT}$ reaction, PCR amplification was performed with 200 nM (MMP-1 and LO) or $1 \mu \mathrm{M}$ (RPL19) primer pairs. Primer pairs for MMP-1 and LO were designed according to the cDNA sequences reported by Quinn et al. (1990) and by Trackman et al. (1990). Primer pairs for RPL19 were the same sequences as reported by Orly et al. (1994). Sense (A) and antisense (B) primers were: MMP-1 A, 5'-TGGCCACTCCCTCGGTCTG; MMP-1 B, 5'TCTCGGGATGGATGCTCGTATG; LO A, 5'-TGTA TAGGCAAAAATGGA; LO B, 5'-TCGCTGTGCTG TGAATC; RPL19 A， 5'-CTGAAGGTCAAAGGGA ATGTG; and RPL19 B, 5'-GGACAGAGTCTTGATG ATCTC. The expected sizes of PCR products were $360 \mathrm{bp}$ for MMP-1, $338 \mathrm{bp}$ for LO and $195 \mathrm{bp}$ for RPL19. The PCR conditions for MMP-1 were $2 \mathrm{~min}$ at $94{ }^{\circ} \mathrm{C}$ for denaturation, followed by the specified number of cycles of $30 \mathrm{~s}$ at $94{ }^{\circ} \mathrm{C}, 30 \mathrm{~s}$ at $60^{\circ} \mathrm{C}$ and $2 \mathrm{~min}$ at $72{ }^{\circ} \mathrm{C}$. Expression of MMP-1 mRNA was weaker than that of RPL19 mRNA, and the proper expressions of both mRNAs were obtained in the same sample by delaying the addition of the primer pairs for MMP-1 by seven cycles. The PCR conditions for LO were 2 min at $94{ }^{\circ} \mathrm{C}$ for denaturation, followed by the specified number of cycles of $30 \mathrm{~s}$ at $94{ }^{\circ} \mathrm{C}, 30 \mathrm{~s}$ at $58{ }^{\circ} \mathrm{C}$ and $2 \mathrm{~min}$ at $72{ }^{\circ} \mathrm{C}$. Expression of LO mRNA was also weaker than that of RPL19 mRNA, and the proper expressions of both mRNAs were obtained in the same sample by delaying the addition of the primer pairs for LO by two cycles. After the PCR reaction, the products were immediately cooled to $4{ }^{\circ} \mathrm{C}$, and $10 \mu \mathrm{l}$ of the products were electrophoresed through a $1.5 \%$ agarose gel containing $0.5 \mu \mathrm{g} / \mathrm{ml}$ ethidium bromide. The resulting bands were examined with a UV transilluminator, and the relative densities were determined by densitometric scanning using the NIHImage program (version 1.60; NIH, Bethesda, MD, USA). In quantitative RT-PCR, the densitometric intensities for the MMP-1 and LO were normalized to that of RPL19. 
Table 1 Effects of Fad on plasma steroid concentrations in pregnant rats. The rats were given s.c. infusion with Fad or vehicle alone (control) from day 14 of pregnancy using a mini-osmotic pump, and steroid concentrations in plasma were determined on day 17 . Values are means \pm S.E.M.

\begin{tabular}{|c|c|c|c|c|c|}
\hline & $\begin{array}{l}\text { No. of } \\
\text { rats }\end{array}$ & $\begin{array}{l}\mathbf{E}_{\mathbf{2}} \\
(\mathrm{pg} / \mathrm{ml})\end{array}$ & $\begin{array}{l}\text { Androstenedione } \\
(\mathrm{ng} / \mathrm{ml})\end{array}$ & $\begin{array}{l}\text { Testosterone } \\
(\mathrm{ng} / \mathrm{ml})\end{array}$ & $\begin{array}{l}\text { Progesterone } \\
(\mathrm{ng} / \mathrm{ml})\end{array}$ \\
\hline \multicolumn{6}{|c|}{ Treatment group } \\
\hline Control & 5 & $29 \cdot 6 \pm 5 \cdot 3$ & $8 \cdot 6 \pm 1 \cdot 5$ & $1 \cdot 2 \pm 0 \cdot 3$ & $85 \cdot 2 \pm 9 \cdot 4$ \\
\hline Fad & 5 & $15 \cdot 7 \pm 1 \cdot 5^{a}$ & $15 \cdot 6 \pm 1 \cdot 1^{b}$ & $2 \cdot 5 \pm 0 \cdot 2^{b}$ & $79 \cdot 4 \pm 6 \cdot 7$ \\
\hline
\end{tabular}

a $P<0.05$ vs controls.

${ }^{\mathrm{b}} P<0 \cdot 01$ vs controls.

\section{Analysis of RT-PCR products}

The PCR product for MMP-1 was analyzed using the restriction enzyme DraI (New England Biolabs, Inc., Beverly, MA, USA). DraI was added to the product at a concentration of $1.64 \mathrm{U} / \mu \mathrm{l}$, and the mixture was incubated for $1 \mathrm{~h}$ at $37^{\circ} \mathrm{C}$. The reaction mixture was electrophoresed through a $2 \cdot 0 \%$ agarose gel containing ethidium bromide. The resulting bands were examined with a UV transilluminator.

The bands of the PCR products for LO in the gel were dissected out on a UV transilluminator, and cDNAs were extracted using a QIAEX II Gel Extraction Kit (Qiagen, Hilden, Germany). By using a TA cloning Kit (Invitrogen, Carlsbad, CA, USA), the purified cDNAs were subcloned into the pCRII plasmid vector, and transformed into INV $\alpha \mathrm{F}^{\prime}$ chemically competent Escherichia coli. The cDNAs in the bacteria were isolated from bacterial solutions originating from three colonies, using a Qiagen Plasmid Mini Kit. Sequences were generated in both directions, using an ABI PRISM Dye Terminator Cycle Sequencing Ready Reaction kit (Applied Biosystems, Branchburg, NJ, USA). Sequencing reactions were analyzed on an ABI Prism 310 Genetic Analyzer (Perkin Elmer, Norwalk, CT, USA). The results were compared using the Genetyx-Mac Version 8.0 software (Software Development, Tokyo, Japan).

\section{Statistics}

Values are expressed as means with S.E.M. Steroid concentrations were evaluated using Student's $t$-test, and the difference between mean values with unequal variances was analyzed by Welch's modified $t$-test. The intrauterine pressure, fetal and placental weights, volume of conceptus, $\mathrm{V}_{\mathrm{z}}$, compliance, collagen content in the uterine ampulla and relative mRNA expressions were analyzed using ANOVA, followed by Fisher's protected least-significant difference post-hoc analysis. Thresholds used to apply the significant difference were 5 or $1 \%$. The Stat View computer program (Hulinks Inc., Tokyo, Japan) was employed.

\section{Results}

Effect of Fad on the plasma steroid concentrations

Table 1 shows the plasma steroid concentrations in the Fad group and the controls on day 17 of pregnancy. The $\mathrm{E}_{2}$ concentration was significantly lower in the Fad group than in the controls. Androstenedione and testosterone concentrations were higher in the Fad group than in the controls, however. The progesterone level did not differ between the groups.

\section{Effect of Fad on the intrauterine pressure and fetuses}

Table 2 shows the effects of Fad on the intrauterine pressure and the fetuses on day 20 of pregnancy. The intrauterine pressure in the Fad group was about four times higher than in the controls. The pressure in the $\mathrm{Fad}+\mathrm{E}_{2}$ group did not differ from that in controls.

Macroscopically, constriction rings between the uterine ampullae were observed in the Fad group. The constriction rings were not found in the controls or the $\mathrm{Fad}+\mathrm{E}_{2}$ group, however. Although no abnormality was found in any live fetuses in the control and the $\mathrm{Fad}+\mathrm{E}_{2}$ group, all rats in the Fad group were carrying injured fetuses, with edematous hematomata on their extremities as shown in Fig. 2. In total, over $20 \%$ of fetuses had injuries on their head or clunis (Table 2). Weights (means \pm S.E.M.) of live fetuses and their placentae were $2 \cdot 18 \pm 0 \cdot 05$ and $0.45 \pm 0.02 \mathrm{~g}$ in the controls, $2 \cdot 29 \pm 0.07$ and $0.43 \pm 0.01 \mathrm{~g}$ in the Fad group, and $2.33 \pm 0.07$ and $0 \cdot 47 \pm 0.03 \mathrm{~g}$ in the $\mathrm{Fad}+\mathrm{E}_{2}$ group. There were no statistically significant differences between these values among the groups.

\section{Effect of Fad on the size and compliance of uterine tissue framework}

Table 3 shows the effects of Fad on the volume of the conceptus and the size and compliance of the uterine tissue framework. There were no significant differences between the volumes of conceptus among the groups. 
Table 2 Effects of Fad on intrauterine pressure and fetal injury in pregnant rats. The rats were given s.c. infusion with Fad or vehicle alone (control) from day 14 of pregnancy using a mini-osmotic pump. Daily s.c. injection of $E_{2}$ took place from day 14 through to day 19. The intrauterine pressure was determined on day 20. Values are means \pm S.E.M.

\begin{tabular}{|c|c|c|c|c|c|c|}
\hline & \multirow[b]{2}{*}{$\begin{array}{l}\text { No. of } \\
\text { rats }\end{array}$} & \multirow{2}{*}{$\begin{array}{l}\text { Intrauterine } \\
\text { pressure } \\
(\mathrm{mmHg})\end{array}$} & \multicolumn{4}{|l|}{ Fetuses } \\
\hline & & & Total no. & $\begin{array}{l}\text { Live normal } \\
(\%)\end{array}$ & $\begin{array}{l}\text { Injured } \\
(\%)\end{array}$ & $\begin{array}{l}\text { Absorbing } \\
(\%)\end{array}$ \\
\hline \multicolumn{7}{|c|}{ Treatment group } \\
\hline Control & 7 & $4 \cdot 6 \pm 0 \cdot 5$ & 84 & $92 \cdot 9$ & 0 & $7 \cdot 1$ \\
\hline Fad & 6 & $16 \cdot 8 \pm 1 \cdot 5^{a}$ & 84 & $56 \cdot 0$ & $22 \cdot 6$ & $21 \cdot 4$ \\
\hline $\mathrm{Fad}+\mathrm{E}_{2}$ & 9 & $5 \cdot 1 \pm 0 \cdot 3$ & 108 & $99 \cdot 1$ & 0 & $0 \cdot 9$ \\
\hline
\end{tabular}

${ }^{a} P<0 \cdot 01$ vs controls or Fad $+\mathrm{E}_{2}$ group.

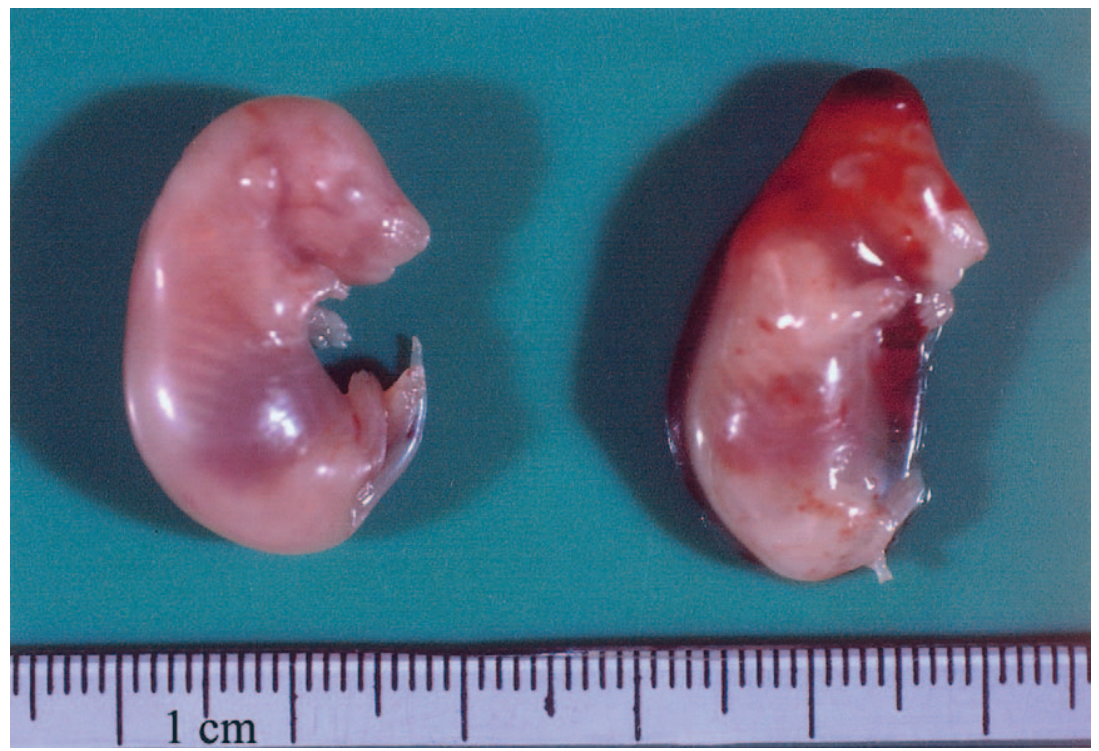

Figure 2 Fetuses on day 20 of pregnancy in a rat treated with Fad, showing a normal live fetus (left) and an injured live fetus bearing a hematoma on the head (right). The mother was given s.c. infusion with Fad from day 14 of pregnancy using a mini-osmotic pump. All fetuses in the vehicle-treated controls and $\mathrm{Fad}+\mathrm{E}_{2}$-treated rats were normal.

The uterine tissue framework at zero pressure, $\mathrm{V}_{\mathrm{z}}$, was significantly smaller in the Fad group than in the control or $\mathrm{Fad}+\mathrm{E}_{2}$ groups. Although the values of $\mathrm{V}_{\mathrm{z}}$ in the control and $\mathrm{Fad}+\mathrm{E}_{2}$ groups were larger than the volume of the conceptus, the value in the Fad group was considerably smaller than the conceptus volume. The compliance was significantly smaller in the Fad group than in the control or $\mathrm{Fad}+\mathrm{E}_{2}$ groups.

Effect of Fad on collagen content and expression of MMP-1 and LO $m R N A$ in the uterus

The collagen content (means \pm S.E.M.) in a uterine ampulla was $7.98 \pm 0.97 \mathrm{mg}$ in the controls $(n=5), 7 \cdot 82 \pm 0.32 \mathrm{mg}$ in the Fad group $(n=5)$, and $7.96 \pm 0.27 \mathrm{mg}$ in the $\mathrm{Fad}+\mathrm{E}_{2}$ group $(n=6)$. The values did not differ among the groups.
Bands of the expected sizes (360 bp for MMP-1, $338 \mathrm{bp}$ for LO and $195 \mathrm{bp}$ for RPL19) were found in the RT-PCR. A negative control for the PCR reaction, in which the reverse transcriptase was omitted, yielded no PCR bands for any of the target mRNAs (not shown).

Using $1 \mu \mathrm{g}$ total RNA, the relationship between cycle number and densitometric intensity of the RT-PCR product for MMP-1 or RPL19 was examined. The densitometric intensity of the band for MMP-1 was linear between 31 and 35 cycles, and for RPL19 (determined at the same time) was linear between 22 and 28 cycles. The quantitative RT-PCR assay was therefore performed at 34 cycles for MMP-1 and at 27 cycles for RPL19. Figure 3A shows the linear response of RT-PCR for MMP-1 and RPL19 vs the concentration of total RNA used for RT; the assay was not linear beyond $500 \mathrm{ng}$ RNA. A further 
Table 3 Effects of Fad on volume of the conceptus and size and compliance of uterine tissue framework in pregnant rats. The rats were given s.c. infusion with Fad or vehicle alone (control) from day 14 of pregnancy using a mini-osmotic pump. Daily s.c. injection of $E_{2}$ took place from day 14 through to day 19 . Values were determined on day 20, and are shown as means \pm S.E.M.

\begin{tabular}{|c|c|c|c|c|}
\hline & & & Uterine tissue fra & \\
\hline & $\begin{array}{l}\text { samples } \\
\text { measured }\end{array}$ & $\begin{array}{l}\text { conceptus } \\
(\mathrm{ml})\end{array}$ & $\begin{array}{l}\text { Size at zero } \\
\text { pressure, } V_{z}(\mathrm{ml})^{\mathrm{a}}\end{array}$ & $\begin{array}{l}\text { Compliance } \\
\left(\times 10^{2} \mathrm{ml} / \mathrm{mmHg}\right)^{\mathrm{a}}\end{array}$ \\
\hline Treatme & & & & \\
\hline Control & 10 & $3 \cdot 67 \pm 0 \cdot 14$ & $4 \cdot 92 \pm 0 \cdot 20$ & $3 \cdot 87 \pm 0 \cdot 40$ \\
\hline Fad & 8 & $4 \cdot 00 \pm 0$ & $2 \cdot 66 \pm 0 \cdot 22^{b}$ & $2 \cdot 18 \pm 0 \cdot 26^{b}$ \\
\hline $\mathrm{Fad}+\mathrm{E}_{2}$ & 9 & $3 \cdot 72 \pm 0 \cdot 12$ & $4 \cdot 52 \pm 0 \cdot 17$ & $3 \cdot 97 \pm 0 \cdot 40$ \\
\hline
\end{tabular}

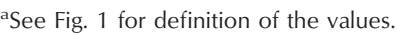

b $P<0 \cdot 01$ vs controls or Fad $+E_{2}$ group.

A

\begin{tabular}{|c|c|c|c|c|c|}
\hline & \multicolumn{5}{|c|}{ Total RNA (ng) } \\
\hline & 31.3 & 62.5 & 250 & 500 & 1000 \\
\hline MMP-1 & manes & baings & Eesen & & Eome \\
\hline RPL19 & 2000 & $\lim _{0}$ & no & & $\mathrm{cos}$ \\
\hline
\end{tabular}

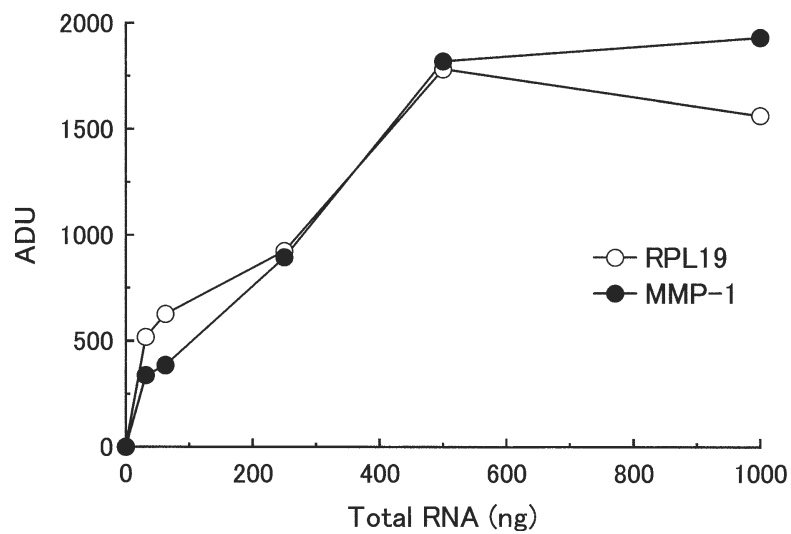

B

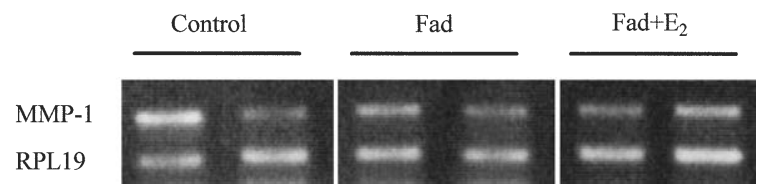

Figure 3 Quantitative RT-PCR assay of MMP-1 and RPL19 transcripts in the uterus of pregnant rats. Total RNA was isolated from the uterine ampulla on day 20 of pregnancy. To obtain proper expressions of both transcripts, addition of the primer pairs for MMP-1 was delayed by seven cycles, and the assay was performed at 34 cycles for MMP-1 and 27 cycles for RPL19. (A) Representative photographic record, and arbitrary densitometric units (ADUs) of the RT-PCR product of MMP-1 and RPL19 shown as a function of the total RNA. (B) Uterine expression of MMP-1 mRNA in controls, Fad-treated rats and Fad+ $\mathrm{E}_{2}$-treated rats are shown in the representative photographic records and as relative values of densitometric units of MMP-1 against that for RPL19 of the RT-PCR products. The rats were given s.c. infusion with Fad or vehicle alone (control) from day 14 of pregnancy using a mini-osmotic pump. Daily s.c. injection with $E_{2}$ took place from day 14 through to day 19 . The assay was performed using 350 ng total RNA. Similar results were obtained when the assay was repeated, and mean values for each sample were taken. Values are means \pm S.E.M. $(n=5)$; there were no significant differences among groups.

assay was performed using 350 ng RNA. Figure 3B shows that the expressions of MMP-1 mRNA were not different among the three groups.

Using $1 \mu \mathrm{g}$ total RNA, the relationship between cycle number and densitometric intensity of the RT-PCR product for LO or RPL19 was examined. The intensity for LO was linear between 20 and 26 cycles, and for RPL19 (determined at the same time) was linear between 22 and 25 cycles. The quantitative RT-PCR assay was therefore performed at 25 cycles for LO and at 23 cycles for RPL19. Figure 4A shows the linear response of RT-PCR for LO and RPL19 vs the concentration of total RNA used for $\mathrm{RT}$; the assay was not linear beyond 62.5-125 ng RNA. A further assay was performed using $62.5 \mathrm{ng}$ RNA. 
A
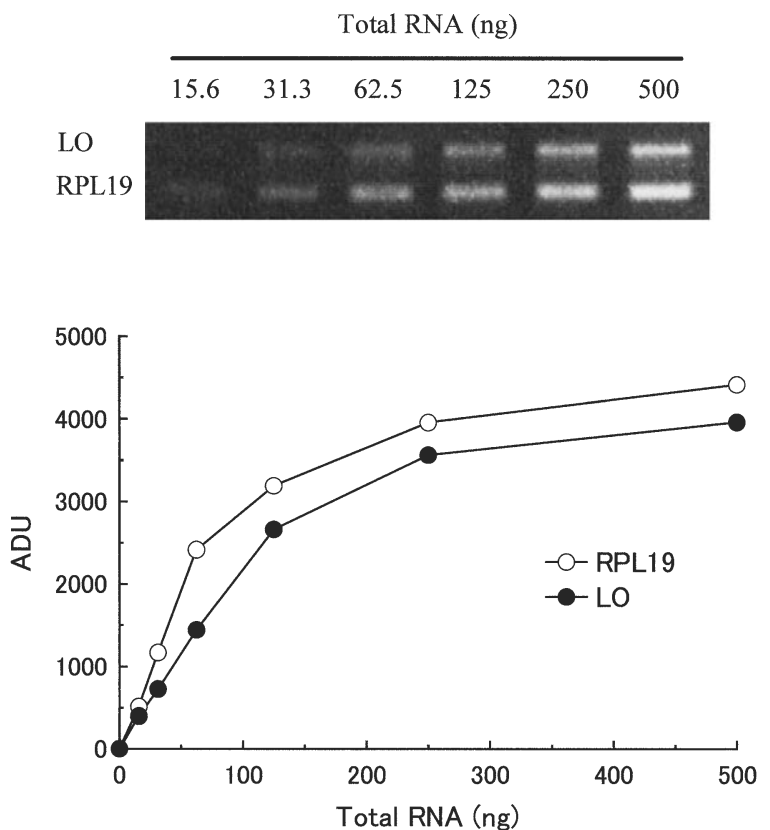

B
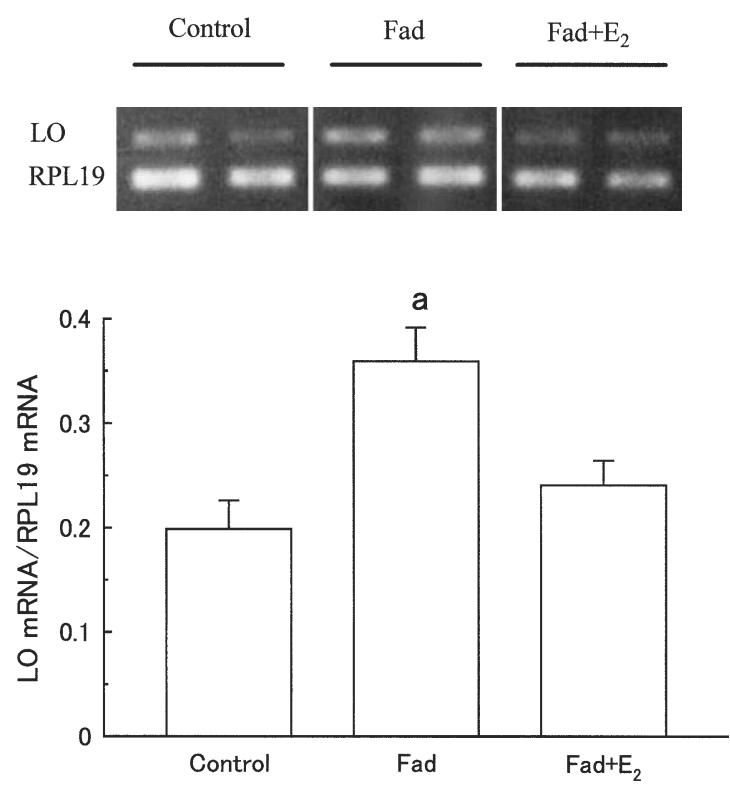

Figure 4 Quantitative RT-PCR assay of LO and RPL19 transcripts in the uterus of pregnant rats. Total RNA was isolated from the uterine ampulla on day 20 of pregnancy. To obtain proper expressions of both transcripts, addition of the primer pairs for LO was delayed by two cycles, and the assay was performed at 25 cycles for LO and 23 cycles for RPL19. (A) Representative photographic record and arbitrary densitometric units (ADUs) of the RT-PCR product of LO and RPL19 shown as a function of the total RNA. (B) The effect of Fad on the uterine expression of LO mRNA is shown in the representative photographic records and as relative values of densitometric units of LO against that for RPL19 of the RT-PCR products. The rats were given s.c. infusion with Fad or vehicle alone (control) from day 14 of pregnancy using a mini-osmotic pump. Daily s.c. injection with $E_{2}$ took place from day 14 through to day 19 . The assay was performed using $62.5 \mathrm{ng}$ total RNA. Similar results were obtained when the assay was repeated, and mean values for each sample were taken. Values are means \pm S.E.M. $(n=5) .{ }^{a} P<0.05$ vs controls or Fad+E 2 group.

Figure 4B shows the expression of LO mRNA in the Fad group was higher than in the control and $\mathrm{Fad}+\mathrm{E}_{2}$ groups.

\section{Analysis of RT-PCR products}

The RT-PCR product for MMP-1 was cut into two fragments of the expected sizes (238 and $122 \mathrm{bp}$ ) by the restriction enzyme DraI (not shown). The cDNA sequence of the RT-PCR product for LO was in complete correspondence with the cDNA sequence for LO mRNA reported by Trackman et al. (1990).

\section{Discussion}

Although progesterone and estrogen are both hormones required for maintaining pregnancy (Courrier 1950), the role of estrogen is not fully known. To study the specific roles of estrogen during the second half of pregnancy, the effects were examined of a non-steroidal aromatase inhibitor of high specific activity, Fad, on the fetuses and uterus in rats. Continuous s.c. infusion of Fad is reported to cause delay of implantation (Tamada et al. 2003) and to be effective in inhibiting estrogen production in rats (Selvaraj et al. 1994, Shetty et al. 1995), so sufficient Fad to inhibit estrogen production was administered using a miniosmotic pump from day 14 of pregnancy. This Fad treatment reduced the plasma $\mathrm{E}_{2}$ concentration and increased levels of androstenedione and testosterone, suggesting that the treatment effectively inhibited aromatase activity. The Fad treatment had no effect on plasma progesterone concentration, however. It has been reported that estrogen stimulates luteal progesterone synthesis (Gibori et al. 1984), and that androstenedione also stimulates progesterone production (Goyeneche et al. 2002). Inhibition of luteal progesterone synthesis due to estrogen deficiency might be overcome by the stimulating effect of the increased androstenedione level.

We have reported that in ovariectomized pregnant rats, progesterone together with estrogen develops the uterine tissue framework to maintain low intrauterine pressure (Ichikawa \& Tamada 1980, Tamada et al. 1984, 1989, 1990). Estrogen deficiency following Fad treatment consistently caused a 4-fold increase in the intrauterine pressure. The uterine constriction rings remained on day 20 of pregnancy. Fetal elongation takes place when the 
intrauterine pressure forces the edges of the amniotic sac into the inter-conceptus rings of the uterine wall, gradually eliminating the constriction rings between the uterine ampullae (Tamada \& Ichikawa 1980). The hematomata observed on the head or clunis of the fetuses in the Fad group might be caused by the extremities of the growing fetuses being pressed onto the constriction rings under abnormally high pressure. To study the physical properties of the uterine tissue framework, the volume-pressure relationship was determined in Ca-free Tyrode's solution containing EGTA, which eliminates uterine contractile activity. The size of the uterine tissue framework at zero pressure, $V_{z}$, was markedly smaller in the Fad group than the volume of the conceptus, suggesting that the conceptuses do consistently suffer from uterine pressure. In the controls, by contrast, $\mathrm{V}_{\mathrm{z}}$ was greater than the volume of conceptuses. Furthermore, Fad treatment reduced the compliance of the uterine tissue framework. Since treatment with $\mathrm{E}_{2}$ restored the changes in uterine physical properties caused by the Fad treatment and prevented fetal injuries, it is possible that the specific role of estrogen during the second half of pregnancy is to develop the uterine tissue framework needed to maintain normal fetal growth in rats. The importance of the uterine physical environment to fetal survival during late pregnancy has been demonstrated in ovariectomized rats and rats treated with a progesterone antagonist (Tamada \& Mori 1995, Tamada et al. 1998). Although high doses of androgens have estrogenic effects and maintain successful pregnancy in the ovariectomized progesterone-treated rats (Hosoda et al. 1984), increased production of androgen in the Fad-treated rats could not have overcome the influences of the estrogen deficiency.

Reticular and collagenous fibers, which consist of bundles of collagen fibrils, extend into extracellular spaces in the uterine smooth muscles to make a network of fibers (Bloom \& Fawcett 1975). Since collagen is mechanically very strong in the soft tissue materials, it is likely to be the main determinant of the physical properties of the uterine tissue framework, as proposed by Cullen \& Harkness (1964). The effects of estrogen on uterine collagen metabolism have been studied. Ryan \& Woessner (1972) showed that administration of $\mathrm{E}_{2}$ to parturient rats strongly inhibits the loss of collagen from the involuting uterus, and found that this effect is due to inhibition of collagen degradation rather than stimulation of collagen synthesis. Furthermore, Woessner (1979) found that injection with $\mathrm{E}_{2}$ causes a decrease in uterine collagenase activity that is correlated with the rate of collagen breakdown. Frankel et al. (1988) found that $\mathrm{E}_{2}$ induces alpha $\mathrm{a}_{2}(\mathrm{I})$ and alpha $\mathrm{a}_{1}$ (III) collagen mRNAs in the immature rat uterus, and Dyer et al. (1980) reported that $\mathrm{E}_{2}$ stimulates both synthesis and degradation of collagen in the ovariectomized rat uterus. It therefore seems that the effect of estrogen on collagen metabolism in the uterus changes according to the physiological state of the animals. Here, during the second half of pregnancy Fad treatment did not affect the collagen content or the mRNA expression of a representative collagenase, MMP-1, in the uterine ampulla. These observations suggest that estrogen deficiency does not have significant effects on either the synthesis or degradation of uterine collagen. Progesterone is reported to retard loss of collagen in the involuting post-partum rat uterus (Halme \& Woessner 1975) and to inhibit the production of collagenase in rat myometrial smooth muscle cells in culture (Jeffrey et al. 1990). During pregnancy, a high level of progesterone might strongly inhibit collagenase production to nullify the influence of estrogen, so maintaining the low constant level of uterine MMP-1 mRNA expression.

LO initiates covalent cross-linking between and within the molecular units of collagen and of elastin by oxidizing peptidyl lysine in these proteins to peptidyl $\alpha$-aminoadipic- $\delta$-semialdehyde. The peptidyl aldehyde can then condense with neighboring amino groups or peptidyl aldehydes to form the covalent cross-linkages found in fibrillar collagen and elastin (Kagan 1986). Patients with cutis laxa, which is characterized by hyperextensible skin, have a deficiency of LO (Kagan 1986, Khakoo et al. 1997). It is therefore possible that the level of uterine expression of LO is closely related to uterine physical properties. The present study has examined for the first time the effect of $E_{2}$ on uterine expression of LO mRNA, and found that estrogen deficiency during pregnancy increases its expression in the rat. The increased LO mRNA expression might have inhibited development of the uterine tissue framework, causing the smaller size and compliance of the uterine tissue framework in the Fad-treated rats.

In conclusion, this study has shown that estrogen deficiency in rats during late pregnancy obstructs the development of the uterine tissue framework that is required for uterine accommodation of the rapidly growing fetuses. As a result, the fetuses are pressed by abnormally high intrauterine pressure and suffer from hematomata on the head or clunis. A high level of uterine expression of the LO gene may be involved in obstructing the development of the uterine tissue framework.

\section{Acknowledgement}

The authors gratefully thank Novartis Pharma (Tokyo, Japan) for the donation of CGS 16949A (fadrozole hydrochloride).

\section{Funding}

This work was supported in part by a Grant-in-Aid for Scientific Research (C) (2) No. 14560269 from the Japan Society for the Promotion of Science. There are no conflicts of interest or potential conflicts of interest. 


\section{References}

Arkaravichien W \& Kendle KE 1992 Fetal viability and fetal growth after prolonged uterine contractions induced by progesterone withdrawal in late pregnancy in rats. Journal of Reproduction and Fertility 96 299-308.

Berg RA 1982 Determination of 3- and 4-hydroxyproline. Methods in Enzymology 82 372-398.

Bloom W \& Fawcett DW 1975 A Textbook of Histology, edn 10, pp 883-889. Philadelphia, PA: WB Saunders.

Chomczynski P \& Sacchi N 1987 Single-step method of RNA isolation by acid guanidinium thiocyanate-phenol-chloroform extraction. Analytical Biochemistry 162 156-159.

Courrier R 1950 Interactions between estrogens and progesterone. Vitamins and Hormones 8 179-214.

Cullen BM \& Harkness RD 1964 Effects of ovariectomy and of hormones on collagenous framework of the uterus. American Journal of Physiology 206 621-627.

Deanesly R 1973 Termination of early pregnancy in rats after ovariectomy is due to immediate collapse of the progesteronedependent decidua. Journal of Reproduction and Fertility 35 183-186.

Dyer RF, Sodek J \& Heersche JNM 1980 The effect of $17 \beta$-estradiol on collagen and noncollagenous protein synthesis in the uterus and some periodontal tissues. Endocrinology 107 1014-1021.

Ford SP, Weber LJ \& Stormshak F 1977 Role of estradiol-17 $\beta$ and progesterone in regulating constriction of ovine uterine arteries. Biology of Reproduction 17 480-483.

Frankel FR, Hsu C-YJ, Myers JC, Lin E, Lyttle CR, Komm B \& Mohn K 1988 Regulation of alpha $2(\mathrm{I})$, alpha $(\mathrm{III})$, and alpha $2(\mathrm{~V})$ collagen mRNAs by estradiol in the immature rat uterus. DNA 7 347-354.

Fuchs A-R 1978 Hormonal control of myometrial function during pregnancy and parturition. Acta Endocrinologica 89 (Suppl 221) 1-69.

Gibori G, Chen YD, Khan I, Azhar S \& Reaven GM 1984 Regulation of luteal cell lipoprotein receptors, sterol contents, and steroidogenesis by estradiol in the pregnant rat. Endocrinology 114 609-617.

Goyeneche AA, Calvo V, Gibori G \& Telleria CM 2002 Androstenedione interferes in luteal regression by inhibiting apoptosis and stimulating progesterone production. Biology of Reproduction 66 1540-1547.

Halme J \& Woessner JF Jr 1975 Effect of progesterone on collagen breakdown and tissue collagenolytic activity in the involuting rat uterus. Journal of Endocrinology 66 357-362.

Hosoda K, Tamada H \& Ichikawa S 1984 The effect of androgen on the maintenance of pregnancy in progesterone-treated ovariectomized rats. Folia Endocrinologica 60 63-69.

Ichikawa S \& Tamada H 1980 The effect of estrogen on uterine plasticity in late pregnant rats. Journal of Reproduction and Fertility $\mathbf{5 8}$ $165-168$.

Jeffrey JJ, Roswit WT \& Ehlich LS 1990 Regulation of collagenase production by steroids in uterine smooth muscle cells: an enzymatic and immunologic study. Journal of Cellular Physiology 143 396-403.

Kagan HM 1986 Characterization and regulation of LO. In Biology of the Extracellular Matrix, vol 1, Regulation of Matrix Accumulation, pp 321-398. Ed. RP Mecham. Orlando, FL: Academic Press.

Kawate N, Yamada H, Suga T, Inaba T \& Mori J 1997 Induction of luteinizing hormone surge by pulsatile administration of gonadotropin-releasing hormone analogue in cows with follicular cysts. Journal of Veterinary Medical Science 59 463-466.

Khakoo A, Thomas R, Trompeter R, Duffy P, Price R \& Pope FM 1997 Congenital cutis laxa and lysyl oxidase deficiency. Clinical Genetics $\mathbf{5 1}$ 109-114.

Kuwahara S, Mizukami T, Omura M, Hagihara M, Iinuma Y, Shimizu Y, Tamada H, Tsukamoto Y, Nishida T \& Sasaki F 2000 Seasonal changes in the hypothalamo-pituitary-testes axis of the Japanese wood mouse (Apodemus speciosus). Anatomical Record $\mathbf{2 6 0}$ 366-372.
Liu W-J \& Hansen PJ 1993 Effect of the progesterone-induced serpin-like proteins of the sheep endometrium on natural-killer cell activity in sheep and mice. Biology of Reproduction 49 1008-1014.

Nagata S-I, Kondou M, Kaneko H, Araki K, Nambo Y, Oikawa M, Watanabe G \& Taya K 1996 A simple defatting method using a partition method of acetonitrile and $n$-hexane for radioimmunoassay of low blood levels of estradiol-17 $\beta$. Journal of Reproduction and Development $42 \mathrm{j} 43-\mathrm{j} 49$.

Orly J, Rei Z, Greenberg NM \& Richards JS 1994 Tyrosine kinase inhibitor AG18 arrests follicle-stimulating hormone-induced granulosa cell differentiation: use of reverse transcriptase-polymerase chain reaction assay for multiple messenger ribonucleic acids. Endocrinology 134 2336-2346.

Quinn CO, Scott DK, Brinckerhoff CE, Matrisian LM, Jeffrey JJ \& Partridge NC 1990 Rat collagenase. Cloning, amino acid sequence comparison, and parathyroid hormone regulation in osteoblastic cells. Journal of Biological Chemistry $26522342-22347$.

Ryan JN \& Woessner JF Jr 1972 Oestradiol inhibits collagen breakdown in the involuting rat uterus. Biochemical Journal 127 705-713.

Selvaraj N, Shetty G, Vijayalakshmi K, Bhatnagar AS \& Moudgal NR 1994 Effect of blocking oestrogen synthesis with a new generation aromatase inhibitor CGS 16949A on follicular maturation induced by pregnant mare serum gonadotrophin in the immature rat. Journal of Endocrinology 142 563-570.

Shetty G, Bhatnagar AS \& Moudgal NR 1995 Blockade of estrogen synthesis with an aromatase inhibitor affects luteal function of the pseudopregnant rat. Journal of Steroid Biochemistry and Molecular Biology 55 347-353.

Tamada H \& Ichikawa S 1980 The effect of estrogen on fetal survival in progesterone-treated ovariectomized rats. Endocrinologia Japonica 27 163-167.

Tamada H \& Mori J 1995 Fetal survival in ovariectomized uterus-incised rats. Laboratory Animal Science 45 281-284.

Tamada H, Yagasaki O \& Ichikawa S 1984 The effect of estrogen on passive length-tension relationship in the uterus of ovariectomized progesterone-treated pregnant rats. International Journal of Fertility 29 239-243.

Tamada H, Nakamura H \& Mori J 1989 Maintenance of low intrauterine pressure by estrogen and progesterone during late pregnancy in rats. Japanese Journal of Animal Reproduction $\mathbf{3 5}$ 193-197.

Tamada H, Ohtani H \& Mori J 1990 The effect of estrogen and progesterone on the volume-pressure curve of the uterine ampulla in late pregnant rats. Endocrinologia Japonica 37 943-947.

Tamada H, Inaba T \& Sawada T 1998 A progesterone antagonist cannot prevent fetal survival if the uterine horn is incised. Endocrine Journal 45 785-789.

Tamada H, Mizuta Y, Kawate N, Inaba T \& Sawada T 2003 Delayed implantation induced by fadrozole hydrochloride in rats. Contraception 68 65-68.

Trackman PC, Pratt AM, Wolanski A, Tang SS, Offner GD, Troxler RF \& Kagan HM 1990 Cloning of rat aorta lysyl oxidase cDNA: complete codons and predicted amino acid sequence. Biochemistry 29 4863-4870.

Woessner JF Jr 1979 Total, latent and active collagenase during the course of post-partum involution of the rat uterus. Biochemical Journal 180 95-102.

Zhang X \& Miller BG 1989 Effects of pregnancy and exogenous progesterone on immunosuppressive activity in the uterus and peripheral plasma of the ewe. Animal Reproduction Science $\mathbf{1 8}$ 253-270.

Received in final form 21 October 2003

Accepted 13 November 2003

Made available online as an

Accepted Preprint 18 November 2003 